\title{
Prologue to the coup of February 1921, Reza Shah's dictatorship
}

\author{
Dr Najleh Khandagh \\ Political Science Faculty of Humanities \\ Tarbiat Modarees University,Tehran, Iran \\ www.najlehkhandagh@gmail.com
}

\begin{abstract}
The period in which political activity in Iran flourished in comparatively free conditions and with considerable vigor was a remarkably brief one when viewed from the perspective of the long history that belongs to Iran. Most historians of Iran regard the emergence of the first political parties as coming with the Constitutional Revolution in 1905-11, and this preliminary stage of political activity lasted until 1921, after Reza Shah coming to power and ruling the country absolutism for twenty years in when the political parties and the trade unions went underground. Reza shah's tyrannical rule and his inclination to Germany in the Second World War, ignored the Anglo-Russian ultimatum. The great powers, mainly Britain and Russia, forced him to resign in favor of his son (Mohammad Reza Shah) in 1941.I shall discuss, the pre period of Reza Shah which gave him opportunity to access to the throne and, I tried to show his dictatorial rule and emphasize on his tyrannical rule.
\end{abstract}

Keywords: Reza Shah, dictatorship, political party, Trades unions, Britain, Russia

\section{RESEARCH METHODOLOGY}

This research was conducted thoroughly on the question of Prologue to the coup of February 1921 and the consequence of Reza Shah's dictatorial rule. This is an analytical study that was accomplished by using libraries and other resources.

The nature of the material resources used in this research has a crucial bearing on the value and reliability of academic work in this particular field. The critiques offered here of preceding my contribution I hope to have made in this area depends upon a fuller and deeper exploration of all available literature and of previously unutilised oral information.

I have tried, to analyze all appropriate materials to fine the critical facts, in this field.

\section{INTRODUCTION}

Although, Reza Shah's reign which lasted from "1925-1941" brought stability to Iran, yet the cost was a great deal of suffering for the people. His policies and the resulting increasing modernization made Iran in fact more dependent upon western consumer imports and aid a heavier burden upon the remaining peasants, as basic articles of food increased considerably in price. (1). Iran played as a buffer state between Britain and Soviet Union to great powers at the time. Iran always had been influenced by Soviet Union, the cause of many problems for Iran, particularly in First and Second World War.

Before Reza Shah; cope (Kudeta) of 1921, Iran was in very bad order, facing economic disaster. The country was plagued by foreign intervention, for example the Anglo- Iranian agreement of 1919, which faced much internal opposition, and the situation within the country worsened to 
the state that numerous revolutionary movement appeared but were negative and purely antiImperialist and were too physically disparate to claim any robustness; however, the way was prepared for the defeat of the QAJAR dynasty and the restraint of British interference. (2)

These disorders communicated to Britain a manifest concern as a result of the Bolshevik revolution of 1917, which Iranian revolutionaries were hoping in part to emulate. The 1921 coup due was the hope for prevention and Reza Khan, on his assumption of power, did bring some political stability to Iran. However, the freedom given to parties and unions was crushed, along with the independence and integrity of the tribes and religious leaders (ULAMA), when the Shah realized the threat which these same bodies could pose to his position. (3)

Although Reza Shah's policies modernized Iran to a modest extent, his tactics were inspired primary by a need to set against each other Great Britain and Russia. Initially he turned to the USA with restricted success and he then resorted to Germany.

The stability brought by Reza Shah is undeniable, but was of a transient and baseless nature and in the long-term damaged Iran's international position, to the extent that his dictatorial rule culminated in the tragedy that was Iran's experience during the Second World War.(4-5)

The strength of Reza Shah's dictatorial proclivities meant that he insisted upon the continued presence of German nationals in Iran, against the demands of the Allied Powers; this effectively justified Anglo-Russian invasion and he was forced to resign in favor of his son Mohammad Reza Shah. (6-7)

\section{Political Awareness And Approval of Constitutional Law}

The nineteenth century in Iran saw a deepening complexity of society which both reflected and effected a general growth of political awareness amongst the population. The QAJAR dynasty, while still claiming to be all-powerful kings of kings, was in the process of losing its absolute power among different section of Iranian society. Provincial magnates had immense power, since the Shahs controlled neither bureaucracy nor armies in their provinces (8). Two new classes also emerged in society: a united middle-class developed gradually out of the lesser clergy and petit bourgeoisie, and a new intelligentsia which welcomed and encouraged westernization grew out of the modernization of the Iranian education system (9). The power of the monarchy was thus being disintegrated, and assumed by groups within society anxious not to further their own careers but the democratic, and thereby stable and confident, state of Iran.

The first manifestation of this political mobilization came in the "Tobacco Protests", in 1892, (10) where a popular ban on smoking forced the cancellation of the tobacco concession given by the government to Britain. Successive proposed concessions were thereafter blocked through the deployment of this newly found popular voice and will, all of which incidents served to strengthen the people's political resolve.

Therefore, with the co-operation of the middle class and intelligentsia, the constitutional law was eventually won from MUZAFFAR AL-DIN Shah through the revolution fought in 1905 (1112). The revolution was supported by the guilds, and by wealthy merchants, religious authorities and intellectual Western-educated people (13).

Many demonstrations took place, the British Consulate in Tehran was also occupied as a place of refuge (14). MUZAFFAR AL-DIN Shah was subsequently compelled to grant a Constitutional Law in face of these and other financial disturbance, so weak was his power (15). 
Despite this triumph, the Constitutionalists had only just begun to encounter problems. MUZAFFAR AL-DIN Shah successor, his son Muhammad Ali Shah, objected strongly to the limits imposed upon the power of the monarch by the Constitutional Law, especially as regards the provinces. He therefore embarked upon a campaign towards its annulment, further antagonizing the situation by sacrificing Iranian interests to those of Czarist Russia in his attempt to favor landowners (16).

In response, an attempt to assassinate Muhammad ALI Shah was made in 1908 by AZADIKHWAHAN (liberals) under orders from HAYDAR KHAN AMUGHLI (17). In June, the Shah with his Iranian Cossacks, under Russian officers, bombarded and dissolved the MAJLES (parliament) (18). Strong resistance ensued, with the conflict between Royalists and Constitutionalists lasting until the autumn of 1909. The victory went to the Constitutionalists, who deposed Muhammad Ali Shah and put his son Ahmad on the throne under a regent. Muhammad Ali Shah was exiled to Odessa, apart from one brief and unsuccessful attempt to regain his throne ('19).

\section{Political Development}

Political diversity and development steadily increased during the whole period. The MAJLES itself divided into 3 factions: the MU TADILIN (Moderates). He AZADIKHWAHAN and the BITARAFAN (neutrals ). The first of these was generally conservative, and the second variously called Nationalist, liberal, extremist and revolutionary; this extremism was active, and manifested itself, for example, in the assassination of ATABAK .The division between the deputies was not a class difference but rather a difference of interest.

Out with the MAJLES- political awareness was being mobilized into organized structures. Three main parties developed out of the ANJUMANS (society) system, ANJUMANS were societies or associations which existed to discuss social freedom and liberation from politically oppressive regimes,: the Democratic Party (Firqa-yi Dimukrat), the MU TADELIN, and the smaller Alliance and Progress Party. The minority Democrat were more influential than the larger MU TADELIN, so the balance of power remained precarious.

Support for the Democrat was basically proletarian in character, coming particularly from the ANJUMANS in Tabriz, from Iranian Turks, and from anti-Royalist Mujahidin, mainly in Baku (20-21). The MU TADILIN comprised pro-Constitutionalist BAKHTIARI Khan and tribesmen, conservative clergy, and landed gentry and was of an upper class nature (22). Iran thus seemed to be moving towards a constitutional and electoral monarchy- the first committee to supervise elections was in fact favored by the Tabriz ANJUMANS, immediately after the Constitution was granted (23). Despite this apparent success, the parties foundered because of the collaboration, necessitated by Germany's rising power.

\section{Foreign Influence And The Reconciliation of Moderates}

As a result of Conventional Treaty of August 31 . 1907 (24), between Britain and Soviet Union, Iran was split into three zones: the North, under the influence of Russia, the South dominated by Britain, while the centre of the country was under the influence of both (25). The Czarist government sought to return Muhammad Ali Shah to power, by provoking counterrevolutionary activity in Iran, and in December 1911, they finally suppressed the remaining Constitutionalist strongholds in Tabriz, Rasht, Port of ANZALI and finally Mashhad in 1912 (26), however, it was also supported, although somewhat ambiguously, by Britain (27-28). 
Earlier in 1911, AZADIKHWAHAN decided to employ American financial advisers, partly because of failure of Belgian officials, partly because of the geographical isolation of the United States, which precluded the temptation of territorial expansion, and partly to counter-balance Russian and British influence. Thus a request was made through the Iranian embassy for trusted financial advisers (29). Morgan Shuster led the group of five financiers appointed in 1911, to whom the MAJLIS gave wide powers covering revenue and expenditure. A Russian ultimatum at this time demanded Shuster's dismissal, compensation for the Russian army, and a guarantee that appointments of foreign advisers would be notified to Russia and Britain.

These demands incited the fury of masses, whose slogan, "Death or Independence", challenged this threat to the very existence of Iranian sovereignty. Upon the MAJLIS rejection of this ultimatum, both Russia and Britain moved forces into the area. As revolutionary forces were engaging the Czarists in Tabriz, Rasht and Mashhad, the Iranian reactionaries, capitalizing on the Russian and British concern, a coup in December of that year. Aided by detachments under the control of YEFREM KHAN the DASHNAK and the BAKHTIARY, they seized the MAJLES building and dissolved Parliament, so that the QAJAR reactionary aristocracy re-assumed power.

The government then accepted, the Russo-British ultimatum, Shuster was dismissed on December 25, 1911, and left Iran on January 11, 1912. ( 30 ). This reconciliation between the Moderates and foreign powers was a setback both for the Democrats and for representative government. A number of liberal leaders fled the country, and the MAJLIS was suspended for 3 years, only recovering in November 1914, after the coronation of Ahmad Shah, when it regained its leading role (31). It was further dissolved again in November 1915, after an attempt to set up a pro-German government in Qum (32-33). Between this event and the sitting of the fourth MAJLIS in June 1921, neither the Liberals nor Nationalists, reputedly honest, participated in Cabinets, since the latter were said to be under either British or Russian influence. The British regarded the Democrats as extremists, who fought intermittently against Russia, Britain and the Iranian government, aided occasional by Germany and Turkey.

Importantly, the end of the Third MAJLIS saw the final collapse of co-operation between the Moderates and Democrats, due to the collaboration of the former group with foreign powers. The Moderates were accused of treachery and betrayal of the nationalists in order to gain power over central government.

\section{Reza Shah's Dictatorship (1921-41)}

"The war ended with Soviet Union in revolution, Turkey powerless and Iran largely destroyed (34)." The success of the October 1917 revolution in the Soviet Union was coupled with revolutionary and anti-imperialist movements within Iran and among some of he neighbor, such as Turkey and Afghanistan. These movements, together with a popular discontent over the 1919 Treaty, persuaded the British to bring about a much more radical (35.) administration; a move which had a probable intentions - to safeguard British interests in Iran, to suppress the revolutionary atmosphere and to keep communism at bay (36). This was initially effected by the formation of a top secret "committee of steel" (37), chaired by SAYYED ZIA (38) and NUSRAT ALLAH-I FIROUZ .This coup, according to MAKKI (39), was masterminded in London. At this stage it was decided to include Reza Khan in the scheme; he was then a colonel in the Cossack Brigade and was forthwith promoted by IRONSIDE to the rank of Commander-in-chief of that brigade. Armed with this new power, Reza Khan marched his force (which was secretly considerably supported by British influences) (40) from Qazvin to Tehran on $21^{\text {st }}$ February, 1921, and carried out a virtually bloodless coup (41). Immediately after the coup, SAYYAD ZIA arrested about 200 officers and other influential people (42). 
Reza Khan, who was born into a military class and had enjoyed a military education, was trusted by the British and even seen by many as a British agent- partly on account of his opposition to Russian Communist infiltration (43-44). At his rise to power in 1921, he was faced with an Iran in social, political and economic chaos, and in which the previous constitutional government had totally failed to achieve any domestic stability; in the towns the population was disgusted by the instability in the country and the consequent and frequent uprisings throughout Iran. These factors, added to a lack of reform and the continuation of foreign intervention, facilitated Reza Khan's coup (45).

The country was governed by SAYYAD ZIA, a supporter of the British (46), and his administration was popularly known as the "black cabinet" (47). A treaty was concluded with the Soviet Union on February $26^{\text {th }}, 1921$, a major consequence of which was the optimistic and grateful Iranian attitude towards the Russian- even Reza Khan, in a newspaper article (48), praised the new relationship reached between the two nations. Despite all the optimism, SAYYAD ZIA was bent on subverting the treaty and to that end he failed to publish all the articles of the agreement. Partly due to this, and also because of the political hostility of Ahmad Shah and his court, and to Reza Khan whose lack of support stemmed from fierce rivalry, SAYYED ZIA lacked popular support, a fact noted by the British; and he was replaced as prime minister by QAVAM on 25th May, 1921. According to BANANI (49.), QAVAM was a friend of the British, whose spying against the Soviet Union he had facilitated during his governorship of KHURASAN. He was also backed by the clerics led by MUDARRIS. As in SAYYED ZIYA's black cabinet, the administration of QAVAM had two latent functions- to suppress internal revolutionary movements, and to undermine the Russo-Iranian relationship (50) Again, because of the general unpopularity of these intentions and conflict with Reza Khan, this cabinet fell- to be replaced by those of MUSTAWFI al-MAMALIK and of MUSHIR al-DAWLA. The actions of the government of MUSHIR al-DAWLA betrayed its very poor pretence of antiBritish, pro-Soviet sympathies, and QAVAM was given the opportunity to return to power. This time, not only did he lack popular support, but at the same time as alienating British friendship, he encouraged good relations with the United States. At this juncture popular support was with Reza Khan who, was showing himself patriotic to Iran and eager to establish good relations with the Soviet Union. ,at least on surface the least. However, at the same time he was presenting to the British an image of support for feudal capitalism, he had, a desire to suppress internal revolutionary movements such as those in Azerbaijan and GILAN and the ability to bring himself to power. (51)

\section{Platform To The Throne}

In 1923, Reza Khan arrested QAVAM and gained the premiership from Ahmad Shah and from these sought to consolidate and improve his general appeal by including within his cabinet nationalists such as MUSADDEQ and left wingers from the social democrats including SULEMAN MIRZA ISKANDARY (52) and pressurize Ahmad Shah to travel to Europe. Meanwhile Reza Khan was supporting agitators who were demonstrating for the declaration of a republic in Iran,(53-54). Later, however, he became a bitter enemy of republicanism. By collaboration with the feudal upper classes, he gained their support in 1924 and then travelled to Qum, where he tried to gain support of clergy in 1924, he made a proclamation calling for an end to demonstrations and seeking untied cooperation for internal reforms. In the same proclamation he called for support for the Monarchy, rather than Republicanism, and gave a convincing impression of being a staunch Muslim. Next he went to Parliament, asking them to grant him the post of commander-in-chief of all the armed forces. The MAJLIS was unwilling to grant him this power, since such a move would have been contrary to article 50 of the constitution and

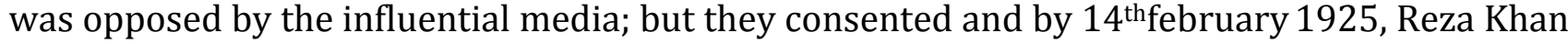


had gained the powers he sought. His ambition was to become Shah and, learning from the experiences of previous prime ministers, he realized that he must secure domestic support for this; he therefore created a party called TAJADDUD (Revolution)- whose manifesto consisted of several promises to the people. For example: lands reforms, political freedom and all citizens were to be treated equally before then law.

Further, his party asked Parliament to abolish the QAJAR dynasty (55). However, after he had become Shah and thus gained supreme power, he broke his word; seizing all the land for himself and banning political parties, he ruled the country personally, (his son succeeding in 1941), without recourse to Constitutional Law.

Further, in 1925 he abolished all workers' unions and arrested 800 union leaders (56). He also arrested the communist party leaders and as a result the Communist party went underground. Reza Shah pursued these anti-Communist policies because he feared Communist influence in opposition to his rule (57).

\section{Accession To The Throne}

On 21 $1^{\text {st }}$ October, 1925, the $5^{\text {th }}$ MAJLIS abolished the QAJAR dynasty on the recommendation of TADDAUN, the Speaker of the MAJLIS and provisional authority was handed to Reza khan. In the interim he published a proclamation advocating the principles of Islam as well as a higher standard of living for the people as his guiding principles; some of the influence authorities believed him and called for popular support for his regime. In November, a Parliamentary election was announced but due to the suspicions of the majority of the population, the voting attendance was minimal. The list of deputies was drawn up by the Army Officers before the election was over, and on $12^{\text {th }}$ December, 1925, the MAJLI ratified Reza Khan's regime, a regime backed by feudal landlords and reactionaries (58.). In fact the regime brought few systematic charges and in effect, continued the status quo.

Upon Reza Khan's elevation to the position of Shah, he concentrated on three major problems; 1- the limitation in the power of the tribes .2- the limitation in the power of the clergy .3- the strengthening of the army to effect his intentions.

Against the treat of the tribes, Reza Shah answered by breaking their backs; (59-60) he forcibly resettled and, oppressed them, and quickly crushed various tribal uprisings.

Another possible threat was the very powerful clergy which he was determined to limit. Therefore he secularized the legal system (61-62) and removed the veil, restricting the movements of women, in effect. "On the $7^{\text {th }}$ January, 1936, Iranian women were formally, ceremoniously, indiscriminately and forcibly unveiled (63). Religious meetings were suppressed by the gendarmerie, and pious foundations were seized (64). An attempt was made to abolish the religious calendar. These actions had two motives; the destruction of SHIISM and the restriction of religious institutions.

As an autocrat, Reza Shah realized the need for an army (65) capable of maintaining his power. The Iranian army he built was assembled on Western, rather than Soviet, principles; and conscription (66) was imposed during 1925. But despite the recruitment of new young officers, Reza Shah's trust and dependence rested on older generals and the army, build to suppress internal trouble, was ineffective against external forces as demonstrated by its helplessness in the invasion of 1941. After suppressing internal opposition Reza Shah turned his attention to external problems. 


\section{Reza Shah's Foreign Policy}

The Soviet attitude to Iran was increasingly favorable after the Bolshevik Revolution and the treaty concluded in 1921 (67) established Iranian rights; (68-69) however Reza Shah did not altogether abide by its terms and ultimately violated it seriously by granting Northern oil concessions to the royal Dutch Shell Company. An intended agreement with the American Company, Armenian Oil, ultimately failed, mainly due to lack of communication within the U.S. administration.

The relation with Britain gradually worsened and the D'ARCY concessions (70) of 1901 decreased in importance as Germany came to replace Britain in the Reza Shah's priorities, although Britain capitulated and signed a new agreement on 29th April, 1933 (71).

In the Middle east, relation with Turkey and Afghanistan had previously been strained due to demarcation disputes and religious differences (72), but a series of treaties was executed, culminating in that of SADAT ABAD (73) between Iran, Turkey, Iraq and Afghanistan on $8^{\text {th }}$ July, 1937, intended to resolve the Shatt al-Arab conflict.

By the 1930s, Reza Shah had established himself as an absolute ruler and tried to consolidate his position commercially by improving the tax system, liquidating capital assets, monopolizing foreign trade and establishing a state bank (74.), to replace the existing British-controlled bank.

Reza Shah thus planned to reduce the British influence which had placed him in power and was threatening to constrain his power, and a further step was taken with the assistance of Germany, a ready ally in an anti-British strategy. In the hiatus left by the American failure German industry and commerce was introduced to the Iranian economy on an increasingly large scale and Germany became the main recipient of goods in Iran's export market in the prewar years, winning $41 \frac{1 / 2 \%}{}$ of Iranian exports in contrast to Britain's $8 \%$.

By $18^{\text {th }}$ October, 1939, Germany's rising importance in Europe too was unquestionable and she had also established a secret Fifth Column within Iran. Encouraged by Germany's position, Reza Shah entered into a clandestine agreement, which allotted her an increased measure of raw materials and the right to build a railway through Iran and to use Iranian airspace . By 1941 German bureaucratic penetration was widespread particularly in governmental institutions, and Germany furthermore commanded emissaries and agents, especially in the north(75), who were capable of perpetrating terrorist activities or sabotage operations in the Baku region of the USSR.

But in order to utilize Iranian territory fully, Germany was eager to persuade her new associate to enter World War II and voiced this proposal on 17th august, 1941. Despite the promise of arms, Iran claimed neutrality, which induced Germany to plan a military coup (76) within Iran, which would bring her policies into line. According to AMINI (77), this coup was to be backed by a division of the Iranian army, led by MANUCHAHRY later called ARYANA.

\section{British And Russia Reaction Towards Reza Shah's German Policy}

Since the invasion of Russia on $22^{\text {nd }}$ June, 1941, Russia had warned Iran three times of the danger of German espionage activities- on $26^{\text {th }}$ June, $19^{\text {th }}$ July and $26^{\text {th }}$ August (78). On $26^{\text {th }}$ June, they signaled the planned coup, and on $19^{\text {th }}$ July they reiterated their warning, adding a reminder of the existence of German agents in Iran, which threatened Russia and Iran itself, and on $16^{\text {th }}$ August and Great Britain handed a formal note to the Iranian government, 
demanding the suppression of German activity in Iran. In return they promised to respect Iranian independence, neutrality and integrity and to work towards developing friendly relations. They conceded that Iran might keep those few Germans who were doing genuinely important technological work and pledged to replace any forced to leave.

A week later Iran gave the following reply (79):

"1. The number of German residents in Iran was no so great as pretended; it scarcely touched the figure of seven hundred (According to Russian sources the number exceeded 3,000); 2. The Iranian government was sure they could not foment any fifth column activities; 3. Iran was reducing the number of foreign specialists in its employ anyway; and 4 the Iranian government believed that the expulsion of Germans from Iran without any logical reasons was against the neutrality of the country."

This reply was not wholly satisfactory, and after a week's attempt to persuade Iran to expel the Germans, they could not make Reza Shah understand the immediate danger both for himself and for his allies, Russian and Britain. For many reasons, economic and strategic, Russian and Great Britain could no longer afford to allow the danger to develop unchecked; they had no choice but action. So on 9 August a Russian ambassador met with Sir R. Bullard to discuss the proposed German coup (which had been envisaged for the period between 22 and 28 august). At 4 a.m. on $25^{\text {th }}$ August, 1941, allied troops crossed the border and attacked Iran by sea, air and ground. The Britain entered at three points from the Persian Gulf to the Turkish border. Russia struck in three areas, in the northwest pushing toward Tabriz and Bandar Pahlavi (ANZALI), and in the northeast advancing towards Mashhad (80). Reza Shah knew that he could not rely on immediate German assistance, but he continued to believe in Germany's final victory. In an effort to maintain his political position for such an eventuality, he commanded the Iranian army to resist (81.). But this action effectively sealed his own fate for the Iranian army quickly disintegrated and the Allies managed to occupy all the important centres in the south (British) and north (Russian) of the country. Churchill described this sudden invasion as "abrupt step". At the time of the invasion 120,000 Iranian troops were included in the fighting (82.). On the same day ambassadors from Great Britain and Russia promised that they would leave when the danger from Germany was over, that they would not interfere with internal affairs, and that the invasion was purely anti-German. These promises were groundless interference, as we have seen, was present, and withdrawal did not take immediately after the expulsion of the Germans from Iran - the British withdrew in March 1946 and the Russians in May, 1946. Although reprehensible at an international level, the Soviet/British invasion at least delivered Iran from the absolutism of Reza Shah. Russia, moreover, could legitimize herself on the grounds of Article 6 of the 1921 Treaty, which stated that "if a foreign power should threaten the frontiers of Federal Russia or those of its allies, Russia shall have the right to advance her troops into the Persian interior (83)." But Britain had no such means of justification. However the Prime Minister could not cope with these problems and on $28^{\text {th }}$ August, Ali Mansur was replaced by the Foreign Minister FOROUGHI and a ceasefire was announced. The Shah was still in control of the situation but found himself under the irreconcilable pressure of two antagonistic domestic forces. A radical group in the army insisted on continuing resistance by political means, whereas most civilian politicians, including Preemie FOROUGHI, were ready to utilize the crisis to overthrow the Shah (84.). Reza Shah inclined to the first group. On the first of September he demanded that the Allies evacuate certain towns and that they pay war reparations; they replied with a demand for the internment of non-diplomatic persons in the German colony. Germany tried to prevent this by intervention and several top German agents managed to escape or to go underground (85.). On $15^{\text {th }}$ September the allied forces began their advance on Tehran. 


\section{Reza Shah's Abdication}

On $16^{\text {th }}$ September Reza Shah was forced to abdicate partly because of his own procrastination, partly due to allied pressure and partly on account of a lack of popular support. Bullard claims that it was the Russian advance to Tehran, not explicit allied pressure, which forced his abdication; Reza Shah's son suggests that his father could not, as a popular leader, rule an occupied country; Reza Shah himself claimed he was making way for a "younger force". He was deported to Mauritius, thence to Johannesburg where he died in 1944.

By the time of Reza Shah's abdication, all of the major landowners and initial leaders and those clergy and politicians who had been in opposition to him, and all the leaders of parties such as the Communist Party had been killed, imprisoned or expelled. Neither at the time of the coup in 1921 nor upon his becoming Shah in 1925 did Reza Khan possess any land or money, but by the time of his abdication he was one of the wealthiest Iranian landowners and one of the world's richest men. According to AHMADI (86), a deputy of the $13^{\text {th }}$ MAJLIS at the time, Reza Shah had 46,000 title deeds to and, the annual value of which over the 17 years of his reign amounted to 30 million dollars (U.S.), and he possessed about 360 million dollars in foreign banks (87), including those of Britain, America and Switzerland. He amassed this by imprisoning or exiling other wealthy landowners and seizing their property for himself (88). He was a principal shareholder in the Anglo- Iranian Oil company and received 12,000 per annum from Britain for shares in the company (89). On his journey from Iran to Mauritius, Reza Shah confided in Kerman to two friends that he had collected 1,000,000,000 dollars during his reign and was now leaving with nothing (90).

Reza Shah banned most political groups and his growing fear of Republicanism and any movement threatening his rule (91) caused the eventual disbanding of all parties. One exception to the ban was Reza Shah's own creation, SAZMAN-I PARVARESH-I After (92), which was little more than Reza Shah's propaganda machine. The lack of political communication meant that Iranian administration was prey to corruption and illegalities .

\section{CONCLUSION}

The period between"1905 - 1921" was one of political and economic turmoil in Iran. Intense political activity derived from the granting of Constitutional law, in 1905. (93) while it was enthusiastically received by the populace, especially in Azerbaijan, it came into increasing disrepute with the new shah," Muhammad Ali Shah"

A power struggle ensued between monarchy and central government. The Constitutionalists, fought right through to 1911. Hostility between east and west centring on each of their individual concerns was of no great importance to the Constitutionalists. Tension was rather caused in Iran itself through the unwanted presence of any foreign influence in the country, although it centred quite naturally on Britain and Russia (94). Both of these powers were seeking concessions from Iran, particularly on oil, and the populace was growing increasingly restive with a government that had neither the capability to restore economic to heal Iran nor the determination to promote the rights of its own citizens in the face of foreign pressure.

These tow source of discontent, deriving from the relation between the central government and foreign powers, induced a rash of revolutionary movements within Iran whose main goals constituted the removal of foreign influence and intervention in Iran, the abolition of Iran's feudal system, and the institution of comprehensive reforms.

Geographically Iran was situated between Britain and Soviet Union and played as a buffer state in $19^{\text {th }}$ and $20^{\text {th }}$ century. Concurrently with the rise of the parties, and in direct response to the 
presence of foreign powers in Iran and their influence over the central government, together with the economic decay within the country, Reza Shah had an opportunity to gain power to rule the country tyrannically for 20 years. Throughout his reign, he controlled the MAJLIS personally, (95) in the elections, in order to choose individuals from local nominations which were predetermined and organized by the Shah.

The judgment passed by the Russian Communist Party from a brief resume of Reza Shah's twenty-year reign, as quoted by MELKOVE: he was "the bitterest enemy of the political freedom of the workers and peasants". He was "the incarnation of the regime of feudal-clerical reaction, who is, and will be, the definitive champion of British Imperialism", and he was the "careerist- adventurer who has tied the State to the military interests of England (96)".

One respected member of the British Parliament commented that Reza Shah had purged Iran of all its thieves and bandits, leaving the country with only one supreme bandit... Reza Shah (97).

\section{References:}

1- RAMAZANI, R. Iran's Foreign Policy 1941-73, , p.28.(Univ. Press of Virginia, CHARLESVILLE . 1975)

2- IBRAHIMYAN, E. 1 Jan. "Oriental Despotism: The Case of QAJAR Iran", International Journal of Middle east Studies, IV, pp.3-31.(1974)

3- IVANOV, M', and TABARI, A , TARIKH-I NUVIN-I Iran, (the new history of Iran) p.91(N.D ) and , Jami a-YI Iran Dar DORAW-I Reza Shah, (Iranian society in Reza shah's reign), p.150.(Tehran, 1976)

4- London Times, 26 Aug. Special Article on Reza Shah.(1941)

5- KHANDAGH.N , the great powers and the middle east, 1984 p.p.48-55 (1984)

6- TABARI, A. Jami a-YI Iran Dar DAWRA-YI Reza Shah, (Iranian society in Reza shah's reign), pp.87-8.(Tehran, 1986)

7- KATOUZIAN,K. Political Economy of Modern Iran 1926-79, p.123 (London, 1981)

8- IBRAHIMYAN, E “"Oriental Despotism: The Case of QAJAR Iran”, International Journal of Middle east Studies, p.25.(1974)

9- Bill , J.A, The Politics of Iran: Groups, Classes and Modernization. .p.47.(USA .1972)

10- Avery, P., Modern Iran, p.223.(New York, 1965)

11- IBRAHIMYAN, E. 'The Crowd in Iranian Politics 1950-53', Past and Present.41, p.192;(1965)

12- Browne, M ; The Persian Revolution of 1905-9, pp.167-168.(1910)

13- IBRAHIMYAN, E. Factionalism in Iran: Political Groups in the $14^{\text {th }}$ Parliament, Middle East Studies, $p$. 192.(1968)

14- IBRAHIMYAN, E, 'Crowd in Iranian Politics', p.186.(1968)

15-IBRAHIMYAN, E. 'The Causes of the Constitutional Revolution in Iran' Middle Easte Studies 10.p.64(1979)

16- RAZI,G ,"Genesis of Party in Iran: A Case Study of the Interaction between the Political System and Political Parties", Iranian Studies, Volume .III ,Issue 2, p.63.(1970)

17- JAWDAT, $\mathrm{H}$, AZ SADR-I MASHRUTIYAT TA INQLAB-I SAFID , (from the beginning of constitution until the white revolution.), p.12.(Tehran, 1970) 
18-RAZI, G. “Genesis of Party in Iran, p.64.(1970)

19- Borderlands of Soviet Central Asia' (no author), Central Asian Review 4, p.300(1956)

20- JAWDAT, H. AZ SADR-I MASHRUTIYAT TA INQLAB-I SAFID , (from the beginning of constitution until the white revolution.), pp.26-7.(Tehran, 1970)

21-MALIK ZADE.M. INQLAB-I MASHRUTIYYAT-I Iran (the constitutional revolution of Iran) Volum.V.pp.803-5 (1954)

22-JAWDAT, H. AZ SADR-I MASHRUTIYAT TA INQLAB-I SAFID , (from the beginning of constitution until the white revolution.), pp.29-31.(Tehran, 1970)

23- RAZI, G. Genesis of Party in Iran “, p.64.(1970)

24- Shuster, M. The Strangling of Persia, pp. 18-25,(1920)

25- Churchill, R.P., The Anglo-Russian Convention of 1907, p.413(1967)

26- Soviet Encyclopedia, art. 'PERSIYA', vol.45.p.223(1940)

27- JAWDAT, H. AZ SADR-I MASHRUTIYAT TA INQLAB-I SAFID , (from the beginning of constitution until the white revolution.), pp.29-31(1970)

28-RAZI, G, Genesis of Party in Iran. pp.64-5.(1970)

29-JAWDAT, H, AZ SADR-I MASHRUTIYAT TA INQLAB-I SAFID , (from the beginning of constitution until the white revolution.), p.35 (1970)

30-Shuster, M. The Strangling of Persia, p.p.66- 198. (1920)

31-RAZI, G. Genesis of Party in Iran, p.66. (1970)

32-Avery, P. Modern Iran, p.95. (1965)

33-MALIK ZADE.M. INQLAB-I MASHRUTIYYAT-I Iran (the constitutional revolution of Iran). Volume Iv p. 945 (1954)

34-London Times .Special Article on Reza Shah, $\left(26^{\text {th }}\right.$ July, 1941).

35-IVANOV, M. TARIKH-I NUVIN-I Iran, (the new history of Iran) . p.44.( N. D)

36-TABARI, A. Jami a-YI Iran Dar DAWRA-YI Reza Shah, (Iranian society in Reza shah's reign) .p.61.(1976)

37-, Avery, P. Modern Iran . p.224. (1965)

38-SULTAN ZADA, H. ASAND-a TARIKHI-YI JNBISH-i KARGARI, SUSIYAL- DEMOKRAT VA KUMUNISTI-YI Iran (the historical documents of the labor, Socialist, and

Communists movement in Iran), Vol.4, p.96.(1973)

39-MAKKI .M. TARIKH-I BIST SALA-YI Iran (Twenty-year history of Iran) , ,volume 3 , p.48.(Tehran, 1944)

40-SULTAN ZADA, H. -a TARIKHI-YI JNBISH-i KARGARI, SUSIYAL- DEMOKRAT VA KUMUNISTI-YI Iran (the historical documents of the labor, Socialist, and

Communists movement in Iran) volume 6 p.205.(1973)

41-BANANI, A, 'The MODERNISATION of Iran -1921-1941' p.36(.Stanford Univ ,California, ,1961)

42-BANANI, A, and SULTANZADE ,H, p.40 (1961) and vol.4, p.96 (1973)

43-MELIKOV, O.S. 'The Dictatorship of Reza Shah', Central Asian Review, vo.10, p.401; (1981) 
44-COTTAM, R and KATOUZIAN, M. Nationalism in Iran, p.193(1964) and 'National Trends in Iran 192126'INTERNATIONAL JOURNAL OF MIDDLE EAST STUDIES , P.538(1979)

45-TULSIRAM, The History of the Communist Movement in Iran, p.51.(Bhopal, 1981) .

46-Avery, P, Modern Iran p.105.(1965)

47-Anonymous, YEK SAFHE AZ TARIKH-I MASHROTE IRAN, (a page from of constitutional history of Iran) (1323), p 57.(1954)

48-GoLSHAN, (Newspaper) $\left(26^{\text {th }}\right.$ June, 1921.)

49-QASEMI, TARIKH-I KHANAVADAHA Dar Iran (the history of Iranian families), p.184.(N .D )

50-IVANOV, M . TARIKH-I NUVIN-I Iran, (the new history of Iran) . pp.66-7.(N.D)

51-KATOUZIAN,K , Political Economy of Modern Iran 1926-79, p.123(London ,1981)

52-TABARI, A , A. Jami a-YI Iran Dar DAWRA-YI Reza Shah, (Iranian society in Reza shah's reign), p. 58.(Tehran .1976)

53-BANANI, A. , Iran-i EMROOZ, (Iran today), p.36.(Tehran, 1965)

54-Banani , A , 'The MODERNISATION of Iran -1921-1941'. p.62;(California. 1961)

55-Iran.(newspaper), 22 Jan, (1925.)

56-S. Mani, S. TARIKHCHA-YI NAHZAT- I KAREGHARI Dar Iran, (the history of labor movement in IRAN) p 105 (Tehran , 1946)

57-TABARI, A , A. Jami a-YI Iran Dar DAWRA-YI Reza Shah, (Iranian society in Reza shah's reign), p. 58.( 1976)

58-IVANOV, M. TARIKH-I NUVIN-I Iran, (the new history of Iran) . pp.93.( N . D)

59-HEJAZI M.B.. 'MODERNISATION and Reform from Above: The Case of Iran', Journal of Politics, vol.32, p.30.( N , D)

60-, Bill, J.A, HAQAYEGH-i GUFTANI, (the truth to be told) p.27. (1945)

61-Saikal,A Iranian Studies, VOL.XI, p.314.(1979)

62-, KEDDIE, N.R, . 'Class Structure and Political power in Iran Since 1796 p.p 305-330(Princeton Univ. 1980)

63-Katouzian.K, p. 128 (London1981)

64-KEDDIE, N. R, Qajar Iran and the Rise of Reza Khan 1796-1925 , p.314.(2012)

65-QAIMMAQAMI, IRANI IMRUZ, (Iran today) (N.D)

66-GROSECLOSE, E, Introduction to Iran, p. 38(1947) and .Tarikh-i Artist-i NUVIN, (The history of new army), Government Publication, Tehran(N .D)

67-TABARI, A , A. Jami a-YI Iran Dar DAWRA-YI Reza Shah, (Iranian society in Reza shah's reign) . p. 58.(1976) 68-FRYE, R. Iran , pp.39, (London, 1953)

69-Marlowe, J, Iran, , pp.72-3(1963)

70-Gregory, L, The Shah and Persia.p .95 (1959)

71-SAIKAL, A. The Rise and Fall of the Shah, p.24.(Princeton U 1980)

72-GROSECLOSE, E. p. 21.(1947) 
73-ELWELL Sutton, Modern Iran, Appendix6, pp.225-229.( 1941) and London Times, special article on Shah. 74-WANNER, J, Reza Shah Pahlavi's Regime and the Penetration of German Imperialism Into Iran Between 1934 and 1940, p.130.(N. D)

75-IVANOV, M and TABARI, A. and London Times. TARIKH-I NUVIN-I Iran, (the new history of Iran) , p.92(N , D) and . Jami a YI Iran Dar DORAW-I Reza Shah, (Iranian society in Reza Shah's reign), p.146(1976) and . London Times, $26^{\text {th }}$ August, 1941

77-AMINI, AZ SEVOM TA BIST- u PANJUM-I SHAHRIVAR, (Third to the twenty-fifth of September) .P.87(1956) 78-IVANOV, M, and , TABARI, A., p. 92(N.D) and p.146(1976) and . London Times, $26^{\text {th }}$ August, 1941.79RAHBAR, no.438, $20^{\text {th }}$ AZAR, 1323 (11 ${ }^{\text {th }}$ December, 1944).

80-London Times ( $26^{\text {th }}$ July, 1941).

81-WANNER, J, Reza Shah Pahlavi's Regime and the Penetration of German Imperialism Into Iran Between 1934 and 1940, p.137.(N. D)

82- KHALILI, M .R VAQEYI-i SHAHRIVAR (the incident of September), VOL.II.(Tehran, N.D.)

83-RAMAZANI, R. The Foreign Policy of Iran 1500-1941:\{ A developing Nation in World Affairs\}, pp.139-167, 186-192.(1964)

84-WANNER, J, , Reza Shah Pahlavi's Regime and the Penetration of German Imperialism Into Iran Between 1934 and 1940, p.138.(N.D)

85-RAMAZANI, R, Iran's Foreign Policy 1941-73, p.28.(1975)

86-IQDAM(Action Newspaper), no.18, .(Tehran 1942)

87-AZHIR(prisoner Newspaper)no. 188,( Tehran.1943)

88-Jami, R., 1976, GUZASHTE CHIRAGH Rah-i AYANDE AST, (the past lights the way for the future), pp. 85105.(1976)

89-FATEMI, M. Panjah Sale NAFT Iran, (50 years of Iranian oil),p . p .25-35( Tehran.1956)

90-BIDARI ( The Awareness newspaper), no.20 (Kerman.)

91-LENCZOWSKI, G, Russia and the West in Iran 1918-48, p.105(1949)

92-RAHBAR (Leader Newspaper), no.438(11 ${ }^{\text {th }}$ December, 1944).

93-LOCKHAT, L “The Constitutional Laws of Persia”, vol.13.p 40 (1959)

94-KEDDIE, N.R. 'Class structure and Political Power in Iran Since 1976', Iranian Studies, VOL.XI, p.314.(1978)

95-MAHJURY, N, and Binder, L. 'ZINDEGH-YI Yak DIVANEH' (the life of a mad person), p. p 19 -22( 1944), and MARD-i IMRUZE, (the man of today), vol.16, p.37.(1962)

96-MELIKOV, O.S, 'The Dictatorship of Reza Shah', Central Asian Review, vo.10, p.405.(1981)

97-Iran-i Ma, (newspaper) , no.567, (Tehran. 1945.) 